\title{
Soil Drench with Fungicides Alternatives Against Root Rot Incidence of Some Vegetables Under Greenhouse Conditions
}

\author{
M. M. Abdel-Kader, N. S. El-Mougy ${ }^{*}$, M. D. E. Aly, S. M. Lashin, R. S. El-Mohamady \\ Plant Pathology Department, National Research Centre, Dokki 12622, Giza, Egypt
}

\begin{abstract}
Soil drench with furfural, Humic \& Folic acid and/or bio-agents treatments were evaluated against root rot incidence of Cucumber, Cantaloupe, Tomato and Pepper in pot experiments. The pathogenic fungi, Fusarium solani, F. oxysporum, Rhizoctonia solani, Sclerotium rolfsii, Sclerotinia sclerotiorum, S. minor, Macrophomina phaseolina, Alternaria solani and Pythium sp. As well as bio-agents, T. harzianum, T. viride, Bacillus subtilis and Pseudomonas fluorescens were used in this study. The obtained results revealed the efficacy of applied some of plant resistance inducers and/or bio-agents as soil drench against tested vegetables root diseases incidence at both pre-, and post-emergence growth stages comparing with untreated control. Applied treatments of the bio-agents in combination with the tested chemicals resulted in higher significant reduction in root rot incidence than each of them alone. Treatments of $T$. harzianum either alone or combined with chemicals were superior for reducing root rot disease for all tested vegetable plants followed by $B$. subtilis treatments comparing with the other tested ones. More detailed studies are required to elucidate formulations of antagonists and alternative fungicides for more successful protection against such soil-borne diseases.
\end{abstract}

Keywords Furfural, Humic \& Folic Acid, Bio-Agents, Root Rot, Vegetables, Soil Drench

\section{Introduction}

Vegetable crops are grown and consumed worldwide and leafy vegetables and fruits in particular provide a source of nutrients and fibre in the human diet. These crops might be consumed fresh or after processing and are produced either on farms with conventional or organic agricultural production methods, or under intensively managed environmentally controlled glasshouses. These vegetable crops are not spared from destruction by fungal pathogens, which infect roots, stems, leaves, flowers and fruits. The challenges for producers in managing these diseases are ever-increasing, as consumer demand for year-round production of fresh vegetables with reduced or no pesticide residues continues to grow. Concerns over the potential impact of disease management practices including the use of fungicides on the environment or on consumer health have prompted producers to examine alternative methods to combat fungal diseases. There is a growing need to develop alternative approaches for controlling plant diseases. Root and stem rot diseases caused by pathogens which survive in soil are responsible for serious losses in vegetables crop yield, e.g. Tomato[1], Can-

* Corresponding author:

nehal_nrc@yahoo.com (N. S. El-Mougy)

Published online at http://journal.sapub.org/ijaf

Copyright (C) 2012 Scientific \& Academic Publishing. All Rights Reserved taloupe[2] and Pepper[3] It was also, recorded that[4] Fusarium stem and root rot of cucumber was observed at four commercial greenhouses in Leamington, Ontario, Canada causing losses of $25-35 \%$.

Present research focuses on finding compounds that are safe to human and environment. An alternative to pesticide application is that, it may be possible to utilize a scheme of inducible plant defences which may provide protection against a broad spectrum of disease-causing pathogenic microorganisms. Furfural [2-Furancarboxaldehyde] is a naturally occurring compound, present in some essential oils and in foods such as bread, baked products, and coffee. It is prepared industrially by treatment with hot sulphuric acid of pentosans contained in agricultural residues, such as cereal straw, brains, and sugarcane bagasse. Furfural is a new pesticide active ingredient intended for the use as a fumigant to control root infesting plant parasitic nematodes and fungal plant diseases. The technical formulation (Furfural Technical) contains $99.7 \%$ furfural and is for the use in formulating end-use products and is applied to growing media and/or soils in greenhouses and field. Also, [5] reported that most of drip irrigation treatments reduced populations of Pythium ultimum and $F$. oxysporum and increased stem height compared with the non treated controls. Metham sodium, furfural + metham sodium, sodium azide, and chloropicrin significantly reduced the incidence of Lateris stem rot caused by Sclerotinia sclerotiorum. One the 
other hand, Humic acid can be applied successfully in many areas of plant production as a plant growth stimulant or soil conditioner for enhancing natural resistance against plant diseases and pests[6,7], stimulation plant growth through increased cell division, as well as optimized uptake of nutrients and water and stimulated the soil microorganisms $[8,9]$. Several reports indicated the efficiency of Humic acid in reducing some plant diseases. In this respect, [7] reported that the most effective treatments for suppression gray mould disease caused by Botrytis cinerea in Geranium plants was compost tea plus kelp extract and HA. Moreover, root rot disease, caused by soilborne pathogenic fungi including Pythium spp., Rhizoctonia spp., Sclerotinia spp. and Fusarium spp. cause widespread, serious economic loss both in greenhouse and field production systems under conditions favourable for disease development. Several studies have shown that some biological control agents (BCAs) such as Trichoderma spp. can reduce the incidence of root diseases caused by soilborne pathogenic fungi[10]. Trichoderma viride is known for its mycoparasitic and antagonistic mechanism for the control of fungal disease. Trichoderma harzianum is a fungal biocontrol agent that attacks a range of pathogenic fungi. Trichoderma harzianum alone or in combination with other Trichoderma species can be used in the biological control of several plant diseases[11-13]. Also, the fluorescent Pseudomonas strains BS8651 and BS8661 reduced damping off of cucumber seedlings caused by $P y$ thium ultimum both following soil drench or seed treatment[14]. Also, soil drench with Pseudomonas fluorescens and Bacillus spp. had the highest effect in reducing the Fusarium wilt of onion caused by Fusarium oxesporum [15].

The objective of the present study was aimed to investigate the efficacy of introduced different fungal, bacterial bio-agents and/or furfural, Humic \& Folic acid (mixture) as pre-planting approach to the cultivated soil against root rot disease incidence under greenhouse conditions.

\section{Materials and Methods}

\subsection{Plant Materials}

Seeds of Cucumber (cv. Alpha), Cantaloupe (cv. Yatherb 7), Tomato (cv. Castel Rock) and Pepper (cv. California) were used in the present study.

\subsection{Fungicides Alternatives}

Furfural and Humic \& Folic acid (mixture) were obtained from El-Nasr Company for chemical industry, Egypt.

\subsection{Pathogenic Fungi}

The tested soilborne pathogenic fungi were Alternaria solani Fusarium solani, F. oxysporum, Rhizoctonia solani, Sclerotium rolfsii, Macrophomina phaseolina and Pythium $\mathrm{sp}$. These fungi were isolated from various vegetables, i.e. Cucumber, Cantaloupe, Tomato and Pepper grown in plastic houses under protected cultivation system and showing root rot and or damping-off disease symptoms[16].

The isolated fungi proved their aggressive ability to induce root rot disease of those vegetables.

\subsection{Bio-agents}

The tested antagonistic fungi were Trichoderma harzianum, T. Viride and Bacillus subtilis and Pseudomonas fluorescens. These antagonists were isolated from cucumber, cantaloupe, tomato and pepper grown in plastic houses under protected cultivation systems and showing root rot disease symptoms[16]. The present bio-agents proved their antagonistic ability against the above mentioned pathogens under in vitro conditions.

\subsection{Greenhouse Experiments}

Evaluation of introduced different fungal, bacterial bio-agents and/or furfural, Humic \& Folic acid (mixture) as pre-planting approach to the cultivated soil against root rot disease incidence under artificial infestation with vegetables root rot causal organisms was performed in pot experiments under greenhouse conditions of Plant Pathology Dept., National Research Centre, Egypt.

For root rot disease evaluation, experiments were carried out in a sandy loam soil artificially infested with root rot pathogens inocula. Inocula of pathogenic fungi, Alternaria solani Fusarium solani, F. oxysporum, Rhizoctonia solani, Sclerotium rolfsii, Macrophomina phaseolina and Pythium sp. were individually grown on autoclaved sand barlly medium $(1: 1, \mathrm{v}: \mathrm{v}+40 \%$ water $)$ for two weeks at $25 \pm 1^{\circ} \mathrm{C}[17]$. The fungal inocula were then mixed together to obtain a mixture contains equal share of tested pathogens. Soil infestation was carried out through amended with a mixture of root rot pathogens inocula (5\% w:w) after[18], then mixed thoroughly to ensure equal distribution of pathogenic fungal inocula. Infested soil was then filled in plastic pots $(30-\mathrm{cm}-$ diameter) and irrigated every second day for 1 week before sowing.

Evaluating the efficacy of different plant resistance inducers, i.e. Furfural, Humic \& Folic acids (as a mixture) and/or bio-agents, i.e. T. harzianum, T. viride, B. subtilis and $P$. fluorescens against root infection were applied as soil drench treatment as follows:

- Furfural at the rate of $5 \%(50 \mathrm{ml} / \mathrm{L})$.

- Furfural $(5 \%)+T$. harzianum $\left(2 \times 10^{4} \mathrm{cfu} / \mathrm{mL}\right)$.

- Furfural $(5 \%)+T$. viride $\left(2 \times 10^{4} \mathrm{cfu} / \mathrm{mL}\right)$.

- Furfural $(5 \%)+$ B. subtilis $\left(2 \times 10^{4} \mathrm{cfu} / \mathrm{mL}\right)$.

- Furfural $(5 \%)+P$. fluorescens $\left(2 \times 10^{4} \mathrm{cfu} / \mathrm{mL}\right)$.

- A mixture of Humic \& Folic acid $0.2 \%(2 \mathrm{ml} / \mathrm{L})$.

- A mixture of Humic \& Folic acid $(0.2 \%)+$ T. harzianum $\left(2 \times 10^{4} \mathrm{cfu} / \mathrm{mL}\right)$.

- A mixture of Humic \& Folic acid $(0.2 \%)+T$. viride $\left(2 \times 10^{4} \mathrm{cfu} / \mathrm{mL}\right)$.

- A mixture of Humic \& Folic acid $(0.2 \%)+B$. subtilis $\left(2 \times 10^{4} \mathrm{cfu} / \mathrm{mL}\right)$.

- A mixture of Humic \& Folic acid $(0.2 \%)+P$. fluorescens $\left(2 \times 10^{4} \mathrm{cfu} / \mathrm{mL}\right)$. 
- T. harzianum $\left(2 \times 10^{4} \mathrm{cfu} / \mathrm{mL}\right)$.

- B. subtilis $\left(2 \times 10^{4} \mathrm{cfu} / \mathrm{mL}\right)$.

- $T$. viride $\left(2 \times 10^{4} \mathrm{cfu} / \mathrm{mL}\right)$.

- P. fluorescens $\left(2 \times 10^{4} \mathrm{cfu} / \mathrm{mL}\right)$.

- Untreated control

For soil drench application, previously infested soil were re-infested at a ratio of $5 \%$ (w:w) with antagonistic fungal cultures or with bacterial cell suspension at the rate of 50 $\mathrm{mL} / \mathrm{kg}$ soil. The tested chemicals were applied as soil irrigation at the rate of one liter $/ 2 \mathrm{Kg}$ soil. The drenched soil was irrigated every second day for 1 week before sowing.

Seeds of Cucumber, Cantaloupe, Tomato and Pepper were surface sterilized (using 3\% sodium hypochlorite for 5 min, then picked up and air-dried), then sown as three seeds per pot, five pots per replicates in each treatment. Another set of soil amended only with a mixture of root rot pathogens (5\% w:w) and sown with surface sterilized seeds was kept as control check treatment. The average percentage of root rot incidence at the pre- and post-emergence of growth stages was recorded up to 15 and 45 days of sowing date, respectively.

\section{Statistical analysis}

All experiments were set up in a complete randomized design. One-way ANOVA was used to analyze differences between applied treatments and disease incidence. A general linear model option of the analysis system SAS[18] was used to perform the ANOVA. Duncan's multiple range test at $P \leq$ 0.05 level was used for means separation[19].

Table 1. Effect of applying antagonistic bio-agents and chemical inducers as soil treatment against vegetables pre-emergence root diseases caused by soil-borne pathogenic fungi under open greenhouse conditions

\begin{tabular}{|c|c|c|c|c|}
\hline \multirow{2}{*}{ Treatment } & \multicolumn{4}{|c|}{ Root diseases incidence (\%) } \\
\cline { 2 - 5 } & \multicolumn{4}{|c|}{ pre-emergence stage } \\
\cline { 2 - 4 } & Cucumber & Cantaloupe & Tomato & Pepper \\
\hline Furfural & $14.7 \mathrm{de}$ & $17.3 \mathrm{de}$ & $19.2 \mathrm{~d}$ & $21.8 \mathrm{c}$ \\
\hline Furfural + T. harzianum & $12.5 \mathrm{de}$ & $9.6 \mathrm{f}$ & $11.4 \mathrm{e}$ & $9.2 \mathrm{f}$ \\
\hline Furfural + T. viride & $32.1 \mathrm{~b}$ & $35.1 \mathrm{~b}$ & $39.6 \mathrm{~b}$ & $40.3 \mathrm{a}$ \\
\hline Furfural + B. subtilis & $13.3 \mathrm{de}$ & $14.4 \mathrm{de}$ & $17.3 \mathrm{de}$ & $17.3 \mathrm{de}$ \\
\hline Furfural + P. fluorescens & $23.6 \mathrm{c}$ & $28.4 \mathrm{bc}$ & $32.9 \mathrm{~b}$ & $35.5 \mathrm{~b}$ \\
\hline Humic \& Folic acid (HF) & $21.4 \mathrm{~d}$ & $21.4 \mathrm{c}$ & $28.8 \mathrm{bc}$ & $32.1 \mathrm{~b}$ \\
\hline (HF) + T. harzianum & $6.6 \mathrm{f}$ & $6.6 \mathrm{f}$ & $6.6 \mathrm{f}$ & $7.0 \mathrm{f}$ \\
\hline (HF) + T. viride & $31.4 \mathrm{~b}$ & $32.5 \mathrm{~b}$ & $38.8 \mathrm{~b}$ & $41.8 \mathrm{a}$ \\
\hline (HF) B. subtilis & $12.9 \mathrm{de}$ & $14.4 \mathrm{de}$ & $16.6 \mathrm{de}$ & $14.7 \mathrm{de}$ \\
\hline (HF) + P. fluorescens & $27.7 \mathrm{c}$ & $30.7 \mathrm{~b}$ & $37.7 \mathrm{~b}$ & $42.5 \mathrm{a}$ \\
\hline T. harzianum & $27.7 \mathrm{c}$ & $25.1 \mathrm{c}$ & $24.7 \mathrm{c}$ & $25.1 \mathrm{c}$ \\
\hline T. viride & $36.2 \mathrm{~b}$ & $34.7 \mathrm{~b}$ & $33.3 \mathrm{~b}$ & $38.1 \mathrm{~b}$ \\
\hline B. subtilis & $29.2 \mathrm{bc}$ & $29.2 \mathrm{bc}$ & $27.3 \mathrm{bc}$ & $26.6 \mathrm{c}$ \\
\hline P. fluorescens & $45.1 \mathrm{a}$ & $43.3 \mathrm{a}$ & $41.1 \mathrm{a}$ & $40.0 \mathrm{a}$ \\
\hline Control & $46.6 \mathrm{a}$ & $45.1 \mathrm{a}$ & $44.7 \mathrm{a}$ & $42.5 \mathrm{a}$ \\
\hline
\end{tabular}

Mean values within columns for each growth stage followed by the same letter are not significantly different $(\mathrm{P} \leq 0.05)$.

* Mixture of equal share of all soil-borne pathogenic fungi

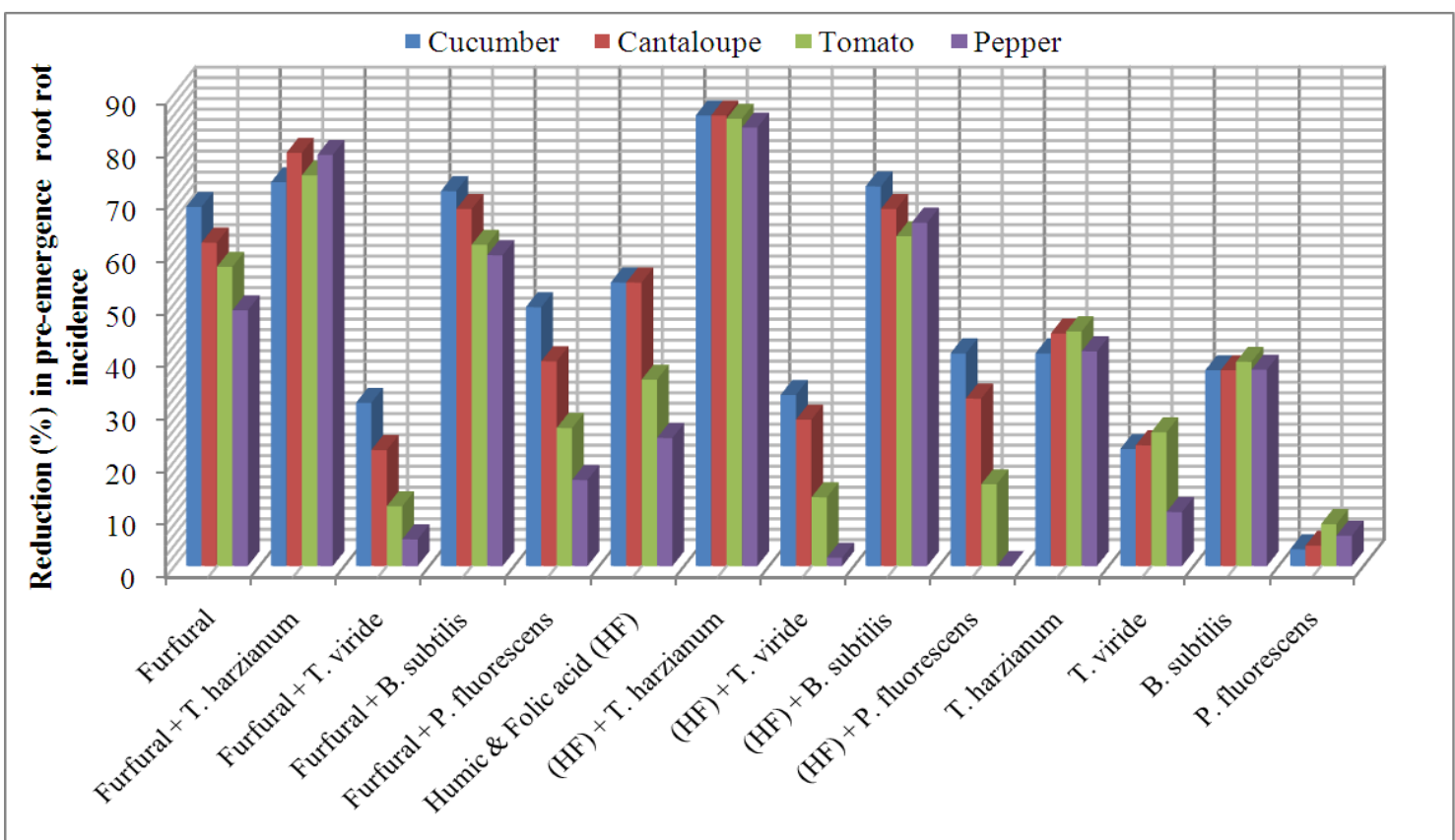

Figure 1. Reduction in vegetables root diseases (Pre-emergence) caused by soil-borne pathogenic fungi in response to applying antagonistic bio-agents and chemical inducers as soil treatment under open greenhouse conditions 
Table 2. Effect of applying antagonistic bio-agents and chemical inducers as soil treatment against vegetables post-emergence root diseases caused by soil-borne pathogenic fungi under open greenhouse conditions

\begin{tabular}{|c|c|c|c|c|}
\hline \multirow{2}{*}{ Treatment } & \multicolumn{4}{|c|}{ Root diseases incidence (\%) } \\
\cline { 2 - 5 } & \multicolumn{4}{|c|}{ post-emergence stage } \\
\cline { 2 - 5 } & Cucumber & Cantaloupe & Tomato & Pepper \\
\hline Furfural & $21.0 \mathrm{f}$ & $26.7 \mathrm{f}$ & $5.5 \mathrm{~h}$ & $26.5 \mathrm{f}$ \\
\hline Furfural + T. harzianum & $23.0 \mathrm{f}$ & $17.1 \mathrm{~g}$ & $7.1 \mathrm{~h}$ & $19.7 \mathrm{~g}$ \\
\hline Furfural + T. viride & $41.5 \mathrm{~d}$ & $38.1 \mathrm{e}$ & $57.8 \mathrm{bc}$ & $58.3 \mathrm{bc}$ \\
\hline Furfural + B. subtilis & $19.0 \mathrm{~g}$ & $21.4 \mathrm{f}$ & $12.0 \mathrm{~g}$ & $23.2 \mathrm{f}$ \\
\hline Furfural + P. fluorescens & $30.5 \mathrm{e}$ & $37.1 \mathrm{e}$ & $40.1 \mathrm{~d}$ & $52.4 \mathrm{bc}$ \\
\hline Humic \& Folic acid $(\mathrm{HF})$ & $27.5 \mathrm{f}$ & $29.4 \mathrm{f}$ & $37.5 \mathrm{e}$ & $41.8 \mathrm{~d}$ \\
\hline (HF) + T. harzianum & $20.5 \mathrm{f}$ & $16.2 \mathrm{~g}$ & $7.4 \mathrm{~h}$ & $16.8 \mathrm{~g}$ \\
\hline (HF) + T. viride & $42.5 \mathrm{~d}$ & $43.0 \mathrm{~d}$ & $49.5 \mathrm{bc}$ & $57.7 \mathrm{bc}$ \\
\hline (HF) + B. subtilis & $23.3 \mathrm{f}$ & $19.6 \mathrm{~g}$ & $3.8 \mathrm{~h}$ & $19.4 \mathrm{~g}$ \\
\hline (HF) + P. fluorescens & $43.6 \mathrm{~d}$ & $55.3 \mathrm{bc}$ & $50.2 \mathrm{bc}$ & $52.6 \mathrm{bc}$ \\
\hline T. harzianum & $0.0 \mathrm{hi}$ & $11.4 \mathrm{~g}$ & $34.9 \mathrm{e}$ & $35.3 \mathrm{e}$ \\
\hline T. viride & $42.6 \mathrm{~d}$ & $42.9 \mathrm{~d}$ & $46.2 \mathrm{~d}$ & $43.1 \mathrm{~d}$ \\
\hline B. subtilis & $3.5 \mathrm{~h}$ & $10.6 \mathrm{~g}$ & $32.1 \mathrm{e}$ & $35.7 \mathrm{e}$ \\
\hline P. fluorescens & $63.5 \mathrm{~b}$ & $56.3 \mathrm{bc}$ & $58.8 \mathrm{bc}$ & $55.8 \mathrm{bc}$ \\
\hline Control & $90.0 \mathrm{a}$ & $89.1 \mathrm{a}$ & $86.7 \mathrm{a}$ & $85.7 \mathrm{a}$ \\
\hline
\end{tabular}

Mean values within columns for each growth stage followed by the same letter are not significantly different $(\mathrm{P} \leq 0.05)$.

mixture of equal share of all soil-borne pathogenic fungi

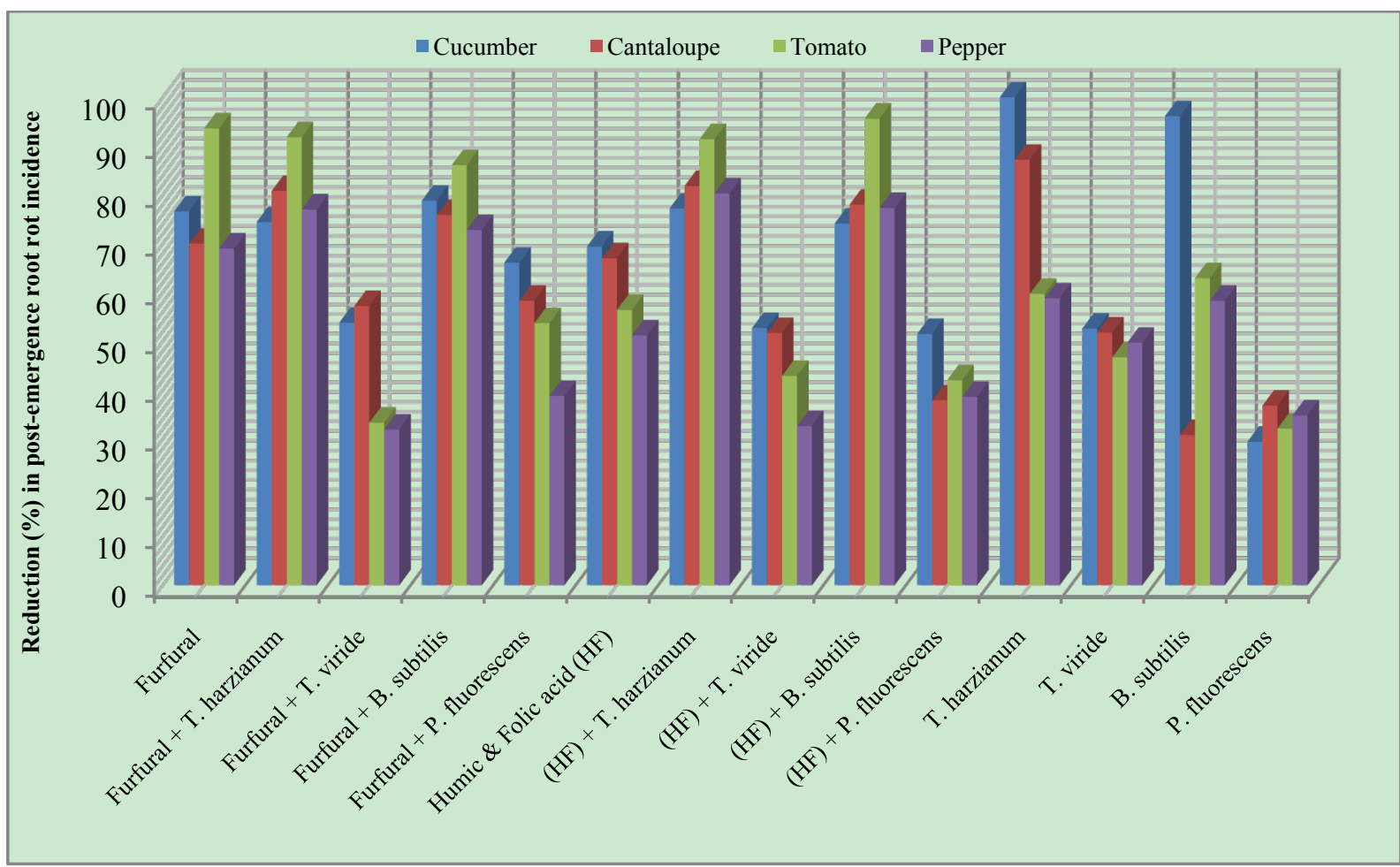

Figure 2. Reduction in vegetables root diseases (Post-emergence) caused by soil-borne pathogenic fungi in response to applying antagonistic bio-agents and chemical inducers as soil treatment under open greenhouse conditions

\section{Results}

The obtained results in Table (1 and 2) and Fig (1 and 2) showed the efficacy of applied chemicals and/or bio-agents as soil drench against tested vegetables root diseases incidence.

Presented data showed that all applied treatments reduced significantly root rot incidence at both pre-, and postemergence growth stages of Cucumber, Cantaloupe, Tomato and Pepper plants comparing with untreated check control. Data also revealed that applied treatments of the bio-agent in combination with the tested inducers resulted in higher significant reduction in root rot incidence than each of them alone. These results were observed in disease incidence recorded at both pre-, and post-emergence growth stages.

In this regard, treatments of $T$. harzianum either alone or combined with chemical inducers were superior for reducing root rot disease for all tested vegetable plants followed by $B$. subtilis treatments comparing with the other tested ones.

The recorded root rot incidence in T. harzianum alone treatment at pre-, and post emergence growth stages was (27.7, 0.0\%) for Cumcuber, $(25.1,11.4 \%)$ for Cantaloupe, $(24.7,34.9 \%)$ for Tomato and $(25.1,35.3 \%)$ for pepper that comparing with untreated control which was $(46.6,90.0 \%)$, $(45.1,89.1 \%),(44.7,86.7 \%)$ and $(42.5,85.7 \%)$, in respective order for testing plants. Moreover, when the T. harzianum 
combined with furfural or the mixture of Humic \& Folic acids (HF) as soil drench application, enhancement of disease reduction was observed. In this concern, at pre- emergence stage the recorded root rot incidence of Cucumber, Cantaloupe, Tomato and Pepper in (T. harzianum + furfural) treatment was 12.5, 9.6, 11.4 and 9.2\% and for (T. harzianum + HF) treatment was 6.6, 6.6, 6.6 and $7.0 \%$ comparing with untreated control $46.6,45.1,44.7$ and $24.5 \%$, respectively.

Similarly, at post-emergence stage, the recorded root rot incidence of Cucumber, Cantaloupe, Tomato and Pepper in (T. harzianum + furfural) treatment was 23.0, 17.1, 7.1 and $19.7 \%$ and for (T. harzianum + HF) treatment was 20.5, 16.2, 7.4 and $16.8 \%$ comparing with untreated control 90.0, 89.1, 86.7 and $85.7 \%$, respectively. Concerning B. subtilis treatments, data in Table (1) and Fig (1) also revealed that, at pre-emergence stage, root rot incidence of Cucumber, Cantaloupe, Tomato and Pepper recorded as 29.2, 29.2, 27.3 and $26.6 \%$ when $B$. subtilis applied alone, while these figures reduced significantly to $13.3,14.4,17.3$ and $17.3 \%$ when $B$. subtilis applied in combination with furfural and as well as to $12.9,14.4,16.6$ and $14.7 \%$ comparing with untreated control $46.6,45.1,44.7$ and $24.5 \%$, respectively.

Also, at post-emergence stage parallel feature was observed for reducing root rot incidence of Cucumber, Cantaloupe, Tomato and Pepper plants. The disease incidence reduced to $19.0,21.4,12.0 \& 23.2 \%$ and $23.3,19.6,3.8 \&$ $19.4 \%$ in (B. subtilis + furfural) and (B. subtilis + HF) treatments, respectively with tested grow plants. Meanwhile, treatments of $B$. subtilis alone caused disease reduction recorded as $3.5,10.6,32.1$ and $35.7 \%$ comparing with untreated control 90.0, 89.1, 86.7 and $85.7 \%$, in respective order for tested vegetables. Data in Table (1) and Fig (1) showed that similar trend was also observed relevant to the other bio-agents $T$. viride and $P$. fluorescens either tested alone or combined with the chemical inducers against root rot disease incidence of Cucumber, Cantaloupe, Tomato and Pepper plants. In this regards, at pre-emergence stage, the disease incidence of tested vegetables was reduced in average to $35.5,42.3 \% \& 36.7,30.1 \%$ and $36.1,34.6 \%$ in $T$. viride and $P$. fluorescens applied alone or combined with furfural or HF treatments comparing with $44.7 \%$ in untreated control. As for post-emergence, root rot incidence soil drenched with $T$. viride and $P$. fluorescens alone or combined with furfural or HF resulted in disease reduction recorded in average as $43.7,58.6 \% \& 48.9,40.0 \%$ and 48.1 , $50.0 \%$, respectively for tested grown vegetables comparing with $87.8 \%$ in untreated control (Table,2 and Fig. 2).

\section{Discussion}

Plant pathogens have caused an almost $20 \%$ reduction in the principal food and cash crops worldwide[20]. These losses may be limited by the use of fungicides, sanitation practices, and crop rotation or by the use of disease-tolerant cultivates. From the ecological point of view natural fungicides are the most important alternative for the use of chemical substances.

Biological control agents (BCAs) inhibit plant pathogens through one or more of the following mechanisms: mycoparasitism, competition for key nutrients and colonization sites, production of antibiotics, or stimulation of plant defence mechanisms[21]. It is well known that, Trichoderma are present in all soil and they are the most cultural fungi. Trichoderma species are strongly antagonistic to other phytopathogenic fungi. They produce hydrolytic enzymes which are believed to play an important role in the parasitism of phytopathogenic fungi. Also, [22] reported that Trichoderma viride was tested for its antagonistic behaviour against pathogen (Bipolaris oryzae). They added that however, this biocontrol agent demonstrates a powerful antagonistic behaviour in the control of rice diseases brown spot. They concluded that Trichoderma viride is an effective biological control agent. Moreover, [23] reported that fluorescent Pseudomonas and Trichoderma harzianum T-22 applied in combination and alone, for controlling Fusarium oxysporum f. sp. lycopersici of tomato was studied in the greenhouse. They found that all biocontrol agents applied individually reduced disease incidence, while treatments as combination showed more protective effect. For the effective biological control of soilborne plant pathogens, a major consideration has been given to proliferation of the antagonist after introduction into the soil. Among the desirable attributes of a successful antagonist is its ability to produce inoculum in excess and to survive, grow, and proliferate in soil and the rhizosphere[24]. The antagonistic organisms have been known to be capable of colonizing in the rhizosphere compatibly responding to the crops $[25,26]$. In many cases, biological control of soilborne plant pathogens was successfully conducted in greenhouse or fields[27-29]. Seed or root rots caused by Pythium spp. were effectively reduced using the antagonistic bacteria Pseudomonas spp. and Bacillus spp. [30-32] and the antagonistic fungi Trichoderma spp.[10,11, 33]. In particular, some antagonistic rhizobacteria such as Burkholderia cepacia [34] and Pseudomonas aeruginosa [35] were very effective against Phytophthora blight in pepper plants under laboratory and greenhouse conditions. In addition to biological control, as a protection method of Phytophthora blight in pepper plants, researches for the effective control of Phytophthora blight by treatment with a non fungicidal synthetic chemical, DL-b-amino-n-butyric acid (BABA), to pepper plants have been conducted. Induction of resistance can be attained by the abiotic inducers such as polyacrylic acid[36], acetylsalicylic acid and salicylic acid [37], and 2,6-dichloroisonicotinic acid[38]. One interesting aspect of biocontrol agent-induced suppression of disease is the reported affect of $T$. harzianum on development of gray mould disease caused by $B$. cinerea through a reduction in its pathogenicity[39,40]. Production of cysteine protease enzymes by Trichoderma was reported to inhibit the activities of hydrolytic enzymes - especially polygalacturonases - in the pathogen, which are important pathogenicity factors in Botrytis and many other fungi[39,40]. The proteases inactivated the pathogen enzyme by cleaving the molecule. Re- 
duction in disease was also demonstrated with extracts containing proteases from Trichoderma culture filtrates and from infected bean leaves, and was reversed by adding protease inhibitors[39]. For such an interaction to be evoked on the plant leaf surface infected with $B$. cinerea, the interacting organisms must spatially and temporally occupy the same niche and be in close proximity to one another, providing localized protection. The potential of Bacillus sp. to synthesise a wide variety of metabolites with antifungal activity is known and in recent years it has been a subject of experiments[41-43]. Most of these substances belong to lipopeptides, especially from surfactin, iturin and fengicin classes. Not so much is known about the mechanism of antifungal activity of these substances produced by Bacillus sp. Some of them (iturin and surfactin) are able to modify bacterial surface hydrophobicity and, consequently, microbial adhesion to surfaces (to mycelium)[41]. Antibiotics of the iturin group were found to act upon the sterol present in the cytoplasmic membrane of the fungi $[43,44]$. Biological control of Aspergillus niger by Bacillus subtilis AF 1 was also investigated by Podile and Parkash[45]. They demonstrated that the bacterial cells initially adhered to the fungus, multiplied and extensively colonized the surface. Rapid growth of bacterial cells on the surface resulted in damage of fungal cell walls.

In the present study combination of bio-agents and fungicides alternatives was also investigated. Similar report[14] reported that several tests revealed that soil drenches or seed treatments of a number of compounds, especially inducers of resistance, combined with strain BS8651 enhanced effectiveness and consistency of the biological control agents against Pythium-damping off in cucumber. Many investigators, explain the role of humic acid in plant diseases reduction. The role of Humic acid in plant diseases may be due to the correlation between these acids and plant health. Humic acid are used both for the production of new cell biomass and to produce energy. Followed by de-animation into the keto acid which inter into the Tri Carboxylic acid (TCA) cycle, which play important role in plant resistance[46]. The role of Humic acid in overcoming the harmful effects of chocolate spot and rust diseases in faba bean plant may be due to the increase in chitinase activity $[47,48]$ and stimulation plant growth through increased cell division, as well as optimized uptake of nutrients and water $[8,9]$ also, regulate hormone level, improve plant growth and enhance stress tolerance[49]. Humic acid is a suspension, based on potassium humates, which can be applied successfully in many areas of plant production as a plant growth stimulant or soil conditioner for enhancing natural resistance against plant diseases and pests[7] which consequently increase yield of plant. Foliar application of HA ( $25 \%$ active HA) consistently enhanced antioxidants such as á-tocopherol, â-carotene, superoxide dismutases, and ascorbic acid concentrations in turf grass species[50]. These antioxidant may play a role in the regulation of plant development, flowering and chilling of disease resistance[51,52]. Amino acids have a chelating effect on micronutrient when applied, that make the absorp- tion and transportation of micronutrients inside the plant is easier due to its effect on cell membrane permeability. Some of these micronutrients play roles in plant resistance by regulating the levels of auxin in plant tissues by activating the auxin oxidase system[53] and by it appears to be required in synthesis of intermediates in the metabolic pathway, through tryptophan to auxin[54]. Consequently auxin lead to increase in total phenol, calcium content and activity of catechol oxidase, these materials protect plants against pathogen stress[55]. However, not much can be found in the literature regarding the efficacy of furfural against fungi and bacteria, the metabolism and effects of furfural in eukaryotic cells have been investigated for yeast cells. In this case, the conversion of furfural depends on the rate of oxidizing in yeasts. Furfural is oxidized to furoic acid under aerobic conditions, and it is reduced to furfuryl alcohol in anaerobic fermentation[56]. The authors indicated that when furfural was added to the culture medium, both cellulose and $\beta$-glucosidase activities decreased with increasing furfural concentration. The activity of both enzymes decreased by $50 \%$ when concentration of furfural increased from 0 to $1.2 \mathrm{~g} / 1$ (1 $200 \mathrm{ppm})$. Furthermore, [57] first studied the fungicidal properties of furfural, reporting control of $R$. solani in potato. More recently, [58] demonstrated that soil treatments with furfural control southern blight caused by $S$. rolfsii in lentil, while stimulating development of Trichoderma spp. and bacteria antagonistic to S. rolfsii. These reports confirm the present findings. Furfural caused the reduction in root-rot incidence, being $75.43 \%$ comparing with untreated control when applied alone. Combined treatments with furfural and either bacterial or fungal bioagents showed a lower effect, although they reduced the disease incidence by more than $41 \%[59]$. A similar effect was also reported for tomato wilt caused by $F$. oxysporum [60] and stem rot of liatris (Liatris punctata) caused by S. sclerotiorum[5]. Moreover, botanical aromatics, furfural, citral and benzaldehyde showed potential for control of both fungal pathogens and phytoparasitic nematodes[61] and they did not reduce colonization of cotton roots by plant growth promoting rhizobacteria (PGPR). Furthermore, Pamphlet sheet of Protect[62,63] has demonstrated efficacy in the control of plant parasitic nematodes and fungal pathogens, i.e. Pythium, Fusarium, Phytophthora and Rhizoctonia. Protect is a contact soil treatment that kills nematodes by irreversibly damaging the cuticle and kills fungi by reacting with the cellular wall and disrupting cellular functions. Also, it is obvious from Multigaurd fate sheet that it controls root infesting plant parasitic nematodes and fungal plant pathogens such as Pythium, Phytophthora, Fusarium and Rhizoctonia.

In conclusion, antagonistic fungal and bacterial bio-agents and/or furfural, Humic \& Folic acid are the effective agents capable of protecting cucumber, cantaloupe, tomato and pepper plants against root rot pathogens under greenhouse conditions. However, more detailed studies are required to elucidate formulations of antagonists and alternative fungicides for more successful protection against such soil-borne 
diseases.

\section{ACKNOWLEDGEMENTS}

This work was supported financially by the Science and Technology Development Fund (STDF), Egypt, Grant No. 1059.

\section{REFERENCES}

[1] Lobo, J.L., Silva, L., 2000, Sclerotinia rot losses in processing tomatoes grown under centre pivot irrigation in central Brazil. Plant Pathology, 49, 51-56. doi: 10.1046/j.1365-3059. 2000. 00394.x

[2] Bruton, U.S., Davis, R.M., Gordon, T.R., 1995, Occurrence of Acremonium sp. and Monosporascus cannonballus in the Major Cantaloupe and Watermelon Growing Areas of California. Plant Dis., 79,754. DOI: 10.1094/PD-79-0754B

[3] Chellemi, D.O., Mitchell, D.J., Kannwischer-Mitchell, M.E., Rayside, P.A., Rosskopf, E.N., 2000, Pythium spp. Associated with Bell Pepper Production in Florida. Plant disease, 84(12), 271 .

[4] Cerkauskas, R.F., Brown, J., 2001, First Report of Fusarium Stem and Root Rot of Greenhouse Cucumber Caused by Fusarium oxysporum f. sp. radicis-cucumerinum in Ontario. Plant disease, 85 (9), 1028.

[5] Gerik, J.S., 2005. Evaluation of Soil Fumigants Applied by Drip Irrigation for Liatris Production. Pl. Dis., 89, 883-887.

[6] Scheuerell, S.J., Mahaffee, W.H., 2004, Compost tea as a container medium drench for suppressing seedling damping off caused by Pythium ultimum. Phytopathology, 94, 1156-1163.

[7] Scheuerell, S.J., Mahaffee, W.H., 2006, Variability associated with suppression of Gray Mold (Botrytis cinerea) on Geranium by foliar applications of nonaerated and aerated compost teas. Plant Dis., 90, 1201-1208.

[8] Atiyeh, R.M., Lee, S., Edwards, C.A., Arancon, N.Q., Metzger, J.D., 2002, The influence of humic acids derived from earthworm processed organic wastes on plant growth. Bioresource Technology, 84, 7-14.

[9] Chen, Y., De Nobili, M., Aviad, T., 2004, Stimulatory effect of humic substances on plant growth. In "Soil organic matter in sustainable agriculture" (Eds F. Magdoff, R.R. Weil). 103-130, Boca Raton, FL.

[10] Sivan, A., Elad, Y., Chet, I., 1984, Biological control effects of a new isolate of Trichoderma harzianum on Pythium aphanidermatum. Phytopathology, 74, 498-501.

[11] Papavizas, G.C., 1985, Trichoderma and Gliocladium: biology,ecology, and potential for biocontrol. Annu. Rev. Plant Pathology, 23, 23-54

[12] Chet, I., 1987, Trichoderma - application, mode of action, and potential as a biocontrol agent of soil borne plant pathogenic fungi. In: Innovative Approaches to Plant Disease Control (Chet, I. ed.), John Wiley \& Sons: New York,
137-160 pp.

[13] Samuels, G.J., 1996, Trichoderma: a review of biology and systematics of the genus. Mycological Research, 100, 923-935.

[14] Vogt, W., Buchenauer, H., 1997, Enhancement of biological control by combination of antagonistic fluorescent Pseudomonas strains and resistance inducers against damping off and powdery mildew in cucumber. Journal of Plant Diseases and Protection, 104 (3), 272-280.

[15] Tehrani, S.A., Ramezani, M., 2003, Biological control of Fusarium oxysporum, the causal agent of onion wilt by antagonistic bacteria. Commun Agric. Appl. Biol. Sci., 68, 543-547.

[16] El-Mougy, N.S., Abdel-Kader, M.M., Abdel-Kareem, F., Embaby, E.I., El-Mohamady, R., Abd El-Khair, H., 2011, Survey of Fungal Diseases Affecting Some Vegetable Crops and Their Rhizospheric Soilborne Microorganisms Grown under Protected Cultivation System in Egypt. Research Journal of Agriculture and Biological Sciences, 7(2), 203-211.

[17] Abdel-Kader, M.M., 1997, Field application of Trichoderma harzianum as biocide for control bean root rot disease. Egypt. J. Phytopathol., 25, 19-25.

[18] Abdel-Kader, M.M., 1999, Biological and chemical control of wilt disease of hot pepper (Capsicum annum L.). Egypt. J. Phytopathol., 27:1-8.

[19] SAS Institute Inc., 1996, 'SAS/STAT user's guide. Version 6. Vol. 2.' 12th edn. (SAS Institute Inc.: Cary, NC) 846 pp.

[20] Winer, B.J., 1971, 'Statistical principles in experimental design.' 2nd edn. (McGraw-Hill Kogakusha Ltd: Tokyo) 596 pp.

[21] Oerke, C., H.W. Dehne, F. Schonbeck, A. Weber, 1994. Crop protection and crop production. Elsevier, Amsterdam,

[22] Va'zquez-Garcidueñas, S., Leal-Morales, C.A., Herrera-Estrella, A., 1998, Analysis of the b-1,3-glucanolytic system of the biocontrol agent Trichoderma harzianum. Appl. Environ. Microbiol., 64,1442-1446.

[23] Gomathinayagam, S., Rekha, M., Sakthivel, S.M., Jagessar, J.C., 2010, The biological control of paddy disease brown spot (Bipolaris oryzae) by using Trichoderma viride in vitro condition. Journal of Biopesticides, 3,:93 - 95.

[24] Yigit, F., Dikilitas, M., 2007, Control of Fusarium Wilt of Tomato by Combination of Fluorescent Pseudomonas, Non-pathogen Fusarium and Trichoderma harzianum T-22 in Greenhouse Conditions. Plant Pathology Journal, 6(2), 159-163.

[25] Baker, K.F., Cook, R.J., 1974, Biological control of plant pathogens. W. H. Freeman \& Co., San Francisco, CA, USA.

[26] Cook, R.J., Baker, K.F., 1983, The nature and practice of bio logical control of plant pathogens. APS. St. Paul, MN, USA.

[27] Schroth, M.N., Hancock, J.G., 1981, Selected topics in biological control. Annu. Rev. Microbiol., 35, 453-476.

[28] Linderman, R.G., Moore, L.W., Baker, K.F., Cooksey, D.A., 1983, Strategies for detecting and characterizing systems for biological control of soilborne plant pathogens. Plant Dis., 67, 
1058-1064.

[29] Weller, D.M., 1988, Biological control of soilborne plant pathogens in the rhizosphere with bacteria. Annu. Rev. Phytopathol., 26,379-407.

[30] Moon, B.J., Schneider, R.W., Park, H.C., 1996, Biological control of seed and seedling rot caused by Pythium arrhenomanes in water-seeded rice. Korean J. Plant Pathol., 12, 407-414.

[31] Kim, D.S., Cook, R.J., Weller, D.M., 1997, Bacillus sp. L324-92 for biological control of three diseases of wheat grown with reduced tillage. Phytopathology, 87,551-558

[32] Yeom, J.R., Park, C.S., 1995, Enhancement of plant growth and suppression of damping-off of cucumber by low temperature growing Pseudomonas fluorescens isolates. Korean J. Plant Pathol., 11,252-257.

[33] Hadar, Y., Harman, G.E., Taylor, A.G., 1984, Evaluation of Trichoderma koningii and T. harzianum from New York soils for biological control of seed rot caused by Pythium spp. Phytopathology, 74,106-110.

[34] Jee, H.J., Nam, C.G., Kim, C.H., 1988, Studies on biological control of Phytophthora blight of red-pepper. I. Isolation of antagonists and evaluation of antagonistic activity in vitro and in greenhouse. Korean J. Plant Pathol., 4, 305-312

[35] Kim, B.S., Hwang, B.K., 1992, Isolation of antibiotic-producing bacteria antagonistic to Phytophthora capsici from pepper growing soils and evaluation of their antibiotic activity. Korean J. Plant Pathol., 8,241-248.

[36] Gianinazzi, S., Kassanis, B., 1974, Virus resistance induced in plants by polyacrylic acid. J. Gen. Virol., 23,1-9.

[37] White, R.F., 1979. Acetylsalicylic acid (aspirin) induces resistance to tobacco mosaic virus in tobacco. Virology, 99:410-412.

[38] Metraux, J.P., Ahl Goy, P., Staub, T., Speich, J., Steinemann, A., Ryals, J., Ward, E., 1991, Induction of resistance in cucumber in response to 2,6-dichloroisonicotinic acid and pathogens. In: Advances in Molecular Genetics of Plant-microbe Interaction, ed. by H. Hennecke and D. P. S. Verma, Vol. 1, pp. 432-439, Kluwer, Dordrecht, The Netherlands.

[39] Kapat, A., Zimand, G., Elad, Y., 1998, Effect of two isolates of Trichoderma harzianum on the activity of hydrolytic enzymes produced by Botrytis cinerea. Physiol. Mol. Plant Pathol., 52, 127-137.

[40] Elad, Y., Kapat, A., 1999, The role of Trichoderma harzianum protease in the biocontrol of Botrytis cinerea. Eur. J. Plant Pathol., 105, 177-189.

[41] Ahimou, F., Jacques, P., Deleu, M., 2000, Surfactin and iturin A effects on Bacillus subtilis surface hydrophobicity. Enz. Microb. Technol., 27, 749-753.

[42] Hathout, Y., HO, Y.P., Ryzhov, V., Demirev, P., Fenselau, C., 2000, Kurstakins: a new class of lipopeptides isolated from Bacillus thuringiensis. J. Natur. Product., 63, 1492-1496.

[43] Moyne, A.L., Shelby, R., Cleveland, T.E., Tuzun, S., 2001, Bacillomycin D: an iturin with antifungal activity against Aspergillus flavus. J. Appl. Microbiol., 90: 622-625.
[44] Worthington, P.A., 1988, Antibiotics with antifungal and antibacterial activity against plant diseases. Nat. Prod. Rep., 5: 47-49.

[45] Podile, A.R., Parkash, A.P., 1996, Lysis and biological con trol of Aspergillus niger by Bacillus subtilis AF 1. Can. J. Microbiol., 42, 533-538.

[46] Bush, D.R., 1993, Proton coupled sugar and amino acid transporters in plants. Annual Review of Plant Physiology and Plant Molecular Biology, 44, 513-542.

[47] Abd El-Kareem, F., 2007, Induced Resistance in Bean Plants Against Root Rot and Alternaria leaf spot Diseases Using Biotic and Abiotic Inducers under Field Conditions. Res.J. Agric. and Biol. Sci., 3(6), 767-774.

[48] El-Ghamry, A.M., Abd El-Hai, K.M., Ghoneem, K.M., 2009, Amino and Humic Acids Promote Growth, Yield and Disease Resistance of Faba Bean Cultivated in Clayey Soil. Australian Journal of Basic and Applied Sciences, 3(2), 731-739.

[49] Piccolo, A., Nardi, S., Concheri, G., 1992, Structural characteristics of humic substances as regulated to nitrate uptake and growth regulation in plant systems. Soil Biochem., 24, 373-380.

[50] Zhang, X., 1997, Influence of plant growth regulators on turfgrasss growth, antioxidant status, and drought tolerance. Ph.D. thesis, Fac. Of Virginia Polytechni (Institute and State University)

[51] Ziadi, S., Barbedette, S., Godard, J.F., Monoti, C., Corre, L.E.D., Silue, D., Lecorre, D., 2001, Production of pathogenesis related protein in the cauliflower (Brassica oleacea var. botrytis) downy mildew (Peronospora parasistica) pathosystem treated with acidbenzolar-5-methyl. Plant Pathol., 50 (5), 579-586.

[52] Achuo, E.A., Audenaert, K., Meziana, H., Hofte, M., 2004, The salicylic acid dependent defence pathway is effective against different fungi in tomato and tobacco. Plant Pathol., $53,65-72$.

[53] Marschner, P., Crowley, D.E., Sattelmacher, B., 1997, Root colonization and iron nutritional status of a Pseudomonas fluorescens in different plant species. Plant and Soil., 196, 311-316.

[54] Ohki, K., 1978, Zinc concentration in soybean as related to growth, photosynthesis, and carboni anhydrase activity. Crop Sci., $18,79-82$.

[55] Chowdhury, A.K., 2003, Control of Sclerotium blight of groundnut by plant growth substances. Crop Research (Hisar), $25,355-359$.

[56] Taherzadeh M.J., Gustafsson, L., Niklasson, C., Lidén, G., 1999, Conversion of furfural in aerobic and anaerobic batch fermentation of glucose by Saccharomyces cerevisiae. J. Biosci. Bioeng., 87, 169-174.

[57] Flor, H.H., 1926, Fungicidal activity of furfural. Iowa State College. J. Sci., 1: 199-227.

[58] Canullo, G.C., Rodriguez-Kabana, R., Kloepper, J.W., 1992, Changes in soil microflora associated with control of Sclerotium rolfsii by furfuraldehyde. Biocontrol Science and Technology, 2, 159-169.

[59] El-Mougy, N.S., El-Gamal, N.G., Mohamed, M.M., Ab- 
del-Kader, M.M., 2008, Furfural approaches as control measures against root rot and root-knot incidence of tomato under greenhouse and field conditions. Journal of Plant Protection Research, 48 (1), 93-105.

[60] Stephan Z.A., Al-Hamadany, M.A., Al-Din, S.S., Dawood, H.B., 2001, Efficacy of furfural treatment in controlling the disease complex of root-knot nematode and Fusarium wilt on tomato and egg plant under Lathouse conditions. Arab. J. P1. Prot., 19, 97-100.

[61] Bauske, E.M., Backman, P.A., Harper, K.M., Brannen, P.M., Rodríguez-Kábana, R., Kloepper, J.W., 1997, Effect of botanical aromatic compounds and seed-surface $\mathrm{pH}$ on growth and colonization of cotton plant growth-promoting rhizobacteria. Biocontrol Science and Technology, 7, 415-421.

[62] Anonymous, 2005, Environmental Fate and Effects Division Review of the New Chemical. U.S. Environmental Protection Agency, Office of Prevention Pesticides. http://www.epa. gov/opprd001/factsheets/furfuralEFEDRA.pdf

[63] Anonymous, 2006, Furfural Chemical Documents. Fact Sheets on New Active Ingredients.U.S. Environmental Protection Agency. http:/www.epa.gov/opprd001/factsheets/ 